\title{
Consumption dynamics during recession and recovery: A learning journey
}

\author{
Maria Sarmento (*) \\ Nova School of Business and Economics, Universidade NOVA de Lisboa, Campus de \\ Campolide, 1099-032 Lisbon, Portugal \\ maria.sarmento@novasbe.pt
}

Susana Marques

University of Aveiro

susana.vasconcelos@ua.pt

Mercedes Galan - Ladero

University of Extremadura, Badajoz, Spain

mgalan@unex.es

(*) corresponding author

Maria Sarmento is grateful to Fundação para a Ciência e a Tecnologia, Portugal (Ref. no SFRH/BPD/ 107886/2015); Fundação para a Ciência e a Tecnologia (UID/ ECO/00124/2013 and Social Sciences DataLab, Project 22209), POR Lisboa (LISBOA-010145-FEDER-007722 and Social Sciences DataLab, Project 22209) and POR Norte (Social Sciences DataLab, Project 22209). 


\begin{abstract}
This paper original contribution builds on examining consumer attitudes in periods of recession and post-recession, providing new insights concerning consumer decision-making, the new logic of spending and saving behavior and also opening new paths for research on the psychology of choice in contexts of recession and the immediate stage of recovery. The study used a longitudinal qualitative approach comprising twenty-two semi-structured interviews with eleven Portuguese consumers. The research was conducted in two moments in time: 2014 and 2018, corresponding to periods of Portuguese recession and recovery. The results show that, during recessions, consumers look for economic level-headedness, adopting and assuming new behaviors that allow them to accommodate the reduced income, which also translates into increased social responsibility. Besides switching to cheaper options, namely looking for private labels and national brand promotions, consumers revealed new strategies and new habits, such as i) more organization and planned behavior; ii) going shopping more frequently; iii) reducing stocking behavior, and iv) avoiding wasting. The study expands the comprehension of consumer behavior during recessions and recovery, bringing the idea of crises as 'learning journeys' and transformational opportunities.
\end{abstract}

Key-words: consumption, consumer behavior; recession; recovery, economic crisis, longitudinal 


\section{Introduction}

The 21st Century economic crisis, which was originated in the United States but extended to other countries and seriously affected Eurozone, has affected consumer behaviour, pressuring consumers to make more rational trade-offs in face of diminished resources. Economic recessions imply contexts of change in lifestyles, consumption patterns and routines, constituting an adequate scenario for studying modifications in consumption (Puelles, Diaz-Bustamante \& Carcelén, 2016; Koos, Vihalemm \& Keller, 2017). According to Quelch and Jocz (2009), when a recession is deeper and more prolonged there is a greater possibility of profound transformations in consumer behaviour.

Despite its relevance and increasing research interest, little is known about consumption decisions during recessions (e.g. Alonso, Rodríguez \& Rojo, 2015, 2017; Kaytaz \& Gul, 2014; Koos et al., 2017). For example, it is critical to better understand how consumers reassess priorities, reallocate funds, switch brands and redefine value (Quelch and Jocz, 2009: 57). The persistence of changes in consumption patterns in the post-recession stage is also overlooked since most part of the research in the field examines behaviour and attitudes at one particular point in time (e.g. Koos et al., 2017; Zurawicki \& Braidot, 2005). Conducting research adopting longitudinal designs is much needed since it allows uncovering changes in consumer attitudes or behavior across time (e.g. Cutler, 1979; Nunes et al., 2011). Consumer behaviour literature needs to accommodate the study/comprehension of these transformations, uncovering dimensions of the psychology of choice in contexts of recession and post-recession which will also allow reassessing the way companies approach consumers during these stages.

This paper original contribution builds on tracking consumer behaviour longitudinally, examining consumers' attitudes in periods of an economic downturn and in the immediate stage of recovery providing new insights concerning consumer decision 
making, the new logic of spending and saving behaviour and also opening new paths for research on the psychology of choice in contexts of economic recession and post-recession. Specifically, this research aims to answer the following questions:

RQ1. What are the crises main implications in consumers everyday life?

RQ2. What are the consumers main expectations regarding a post-crisis stage?

RQ1. How can we characterize consumer behaviour in the crisis recovery stage?

RQ4. What are the consumer perceptions of positive and negative crisis outcomes? The study used a longitudinal qualitative approach comprising twenty-two semi-structured interviews with eleven Portuguese consumers. The research was conducted in two moments in time: 2014 and 2018, corresponding to periods of Portuguese recession and recovery.

\section{Literature review}

\subsection{Consumer decision-making and (bounded) rationality}

Consumer behavior is a complex function of many known and unknown factors, including economic but also psychological, sociological and cultural variables (Jacoby, 2000). To understand consumption modification in changing and complex contexts (like the ones of deep recessions) it is imperative to use an integrative and multidimensional lens that combines consumer psychological perspectives with assumptions of utility maximization and rational decisions. Jacoby (2000:107) argues that "rather than 'maximizing', most consumer behavior reflects 'satisficing', that is, settling for an acceptable ('good enough') option out of the universe of possible purchase alternatives". Because it is infrequent for anyone to be aware of all the possible options, it is only likely that the decision maker selects the best option from among those known to him (rather than the optimal option from all possible options). This choice-set 'bounds' the decision maker's rationality. 
The argument that fully rational decision-making is 'bounded' by limited cognitive capacity is being increasingly demonstrated in the literature, both theoretically and empirically (e.g. Ehrlinger, Readinger \& Kim, 2015; Mathis \& Steffen, 2015). The integration of psychology into neoclassic economics has developed the field of behavioral economics, that heavily documents systematic deviations (biases) from the rational behavior assumed in standard economics (The Royal Swedish Academy of Sciences, 2017).With his theory on Mental accounting, Richard H. Thaler* makes a radical break with the traditional economic model of utility-maximizing consumers (Thaler, 1985, 1999). The theory is a psychological theory of how household behaviors, in particular spending and saving behaviors are affected by limited cognition. "The primary reason for studying mental accounting is to enhance our understanding of the psychology of choice" (Thaler, 1999: 184). The theory is based on the empirical evidence that people group their expenditures into different categories (e.g. housing, food, clothes) and each category corresponds to a separate mental account. As argued by Thaler $(1985,1999)$, mental accounts help individuals to simplify their financial decision-making and help to explain how people think about money, suggesting the piecemeal nature of decision-making. Mental accounting informs expenditure and budgeting decisions, helping consumers to "keep trace of where their money is going, and to keep spending under control" (Thaler, 1999: 184). This mechanism facilitates the budgeting process through rational trade-offs between competing options and, simultaneously, it can work as a self-control instrument. The rationale of behavioral economics is starting to be explored in the context of recessions (see Strutton \& Lewin, 2012). In a context of financial prudence and limited budgets, it is expected that budgeting rules will be quite explicit.

\footnotetext{
* The 2017 recipient of the Nobel Memorial Prize in Economic Sciences for his contributions to behavioral economics
} 


\subsection{Crises, business dynamics and consumption}

Recessions affect business performance, even though the crisis effects differ between companies (Srinivasan et al., 2005). Some businesses face cash flow challenges as banks and suppliers difficult financial terms (Ang et al., 2000) or suffer cut back (Srinivasan et al., 2005), while other firms find opportunities to strengthen their businesses investing and achieving a competitive advantage (Srinivasan et al., 2005). According to Ang et al. (2000: 97\&108) examples of firms' strategies during recessions are: i) withdrawing from weak markets, fortifying in markets where brand is strong, acquiring weak competitors, expanding into crisis resistant markets, and considering resale market for durable products; ii) introducing secondline brands ("fighter lines") and developing adaptive positioning; iii) maintaining prices while improving quality (or reducing price while maintaining quality), avoiding reducing quality and price; iv) pruning marginal dealers, and considering alternative channels; and (v) increasing promotional spending (using informative advertisements) and introducing loyalty programs, to avoid losing value-conscious consumers (e.g. Burton et al., 1998; Garretson et al., 2002; Kaswengi \& Diallo, 2015).

Economic recovery changes the market landscape and demands different business strategies. Piercy et al. (2010, p.3) propose an agenda for executives to address those new challenges and opportunities: overcoming resistance to change; reinventing marketing strategy for a new market environment; prioritizing market sensing; innovating radically in product strategy; re-thinking marketing communications; developing value based competitive advantage; and, repairing damaged value chain relationships. This agenda helps executives to responding to the increasing demands and changing expectations of recession and post-recession customers (Quelch \& Jocz, 2009). 
Crises affect consumption on multiple levels and ways, with a major impact on lifestyles, consumption patterns, routines, worldviews and well-being (Koos et al. 2017). Considering the profound and structural changes caused by crises, it is crucial to further study and understand consumer responses, including adaptation, coping strategies and social resilience. Research on the effects of crises on consumption is increasing in the fields of sociology and marketing (e.g. Koos et al. 2017; Alonso, Rodríguez, \& Rojo, 2015, 2017; Hampson et al., 2018; Hampson \& McGoldrick, 2013).

Different aspects of crises and consumption are being examined including the changing process of household budget allocations (Du \& Kamakura, 2008; Kamakura \& Du, 2012), consumer price consciousness (Hampson \& McGoldrick, 2017), calculative price behavior (Berdysheva \& Romanova, 2017), the role of private labels and discount stores (Puelles et al., 2016; Lamey, Deleersnyder, Dekimpe, \& Steenkamp, 2007), adaptive shopping patterns (Hampson \& McGoldrick, 2013), consumers' money attitudes in the postrecession economy (Hampson et al., 2018), social and political discourses (Alonso, Rodríguez, \& Rojo, 2015, 2017), media discourses (Vihalemm, Keller, \& Pihu, 2016), ethnocentric consumption (Lekakis, 2017), social innovation and community-based responses (Blättel-Mink et al, 2017), communal exchange and social resilience (Garner, 2017) and collaborative consumption (Lindlbom \& Lindlbom, 2017).

Recently, Koos et al. (2017) developed a conceptual framework, more encompassing and cohesive for the study of crises, consumption and social resilience on markets. Their purpose is to overcome the limitations and shortcomings of existing models through a broader, analytical and more multidisciplinary perspective: going beyond the purchase dimension of consumption to include usage and disposal; considering, very explicitly, the broader social, cultural, economic and institutional context of consumption; linking specific response strategies to specific consumer characteristics like social class, identity or cultural 
and economic resources of consumers. The proposed model distinguishes between contextual influences, individual capabilities and different consumption strategies, assuming a dynamic relationship between them.

\subsection{Consumers' coping strategies}

Crises affect individual consumers through a direct tangible or an indirect cognitive/emotional mechanism (Koos, 2015; Koos et al, 2017). They can have tangible, direct impacts on the monetary resources available to people for their daily consumption decisions. At the same time, and even when there are no significant material constraints and deprivation, crises can deeply affect consumption attitudes and behavior, consumers' everyday life, their concerns, feelings and perspectives about the future. Crises, thus, have the potential to undermine the innate belief in the taken for granted stability and structure of our life world (Koos et al., 2017, p. 365). This potential impact is very explicit on the critical and pessimistic narratives of Spanish citizens, independently of their class position, as empirically demonstrated by Alonso et al. (2017).

Existing literature provides good evidence concerning consumers coping strategies. There is an empirical demonstration that during recessions consumers become more concerned about their financial security (e.g., Kamakura \& Du, 2012; Xiao and O’Neill, 2016; Zurawicki \& Braidot, 2005), more frugal and more price conscious (Hampson \& McGoldrick, 2017; Hampson \& McGoldrick, 2013; Steenkamp \& Maydeu-Olivares, 2015). As highlighted by Hampson \& McGoldrick (2017), there are psychological mechanisms and stressors that help to explain why consumers feel affected well beyond the technical end of a recession. Besides the relevance of economic stressors, their findings demonstrate the effect of consumer anticipated guilt and smart shopper self-perception on price consciousness. 
During recessions, consumers tend to buy less, more frequently, in smaller packages, search for more information and evaluate alternatives more carefully (Ang et al., 2000, McKenzie \& Schargrodsky, 2005). They adopt more simple, savvy and prudent lifestyles (Du \& Kamakura, 2008; Hampson \& McGoldrick, 2013; Strutton \& Lewin, 2012), increasing spending on private labels and on discount stores (Lamey et al., 2007; Hampson \& McGoldrick, 2013), postponing the purchase of durables (Deleersnyder et al., 2004) and delaying purchases of luxury items and reducing purchases of status-rich goods (Ang et al., 2000; Kamakuru \& Du, 2012). These pieces of evidence show that it is not only a matter of material deprivation and the resulting need of consuming less. It is also a matter of learning to consume differently and in a more intelligent way. In line with this reasoning, Hampson \& McGoldrick (2013) go beyond the study of spending adaptations to include broader shopping behavior change and related attitudes. At an aggregate level, their findings provide evidence of a more knowledgeable and less impulsive shopper, more concerned with value and purchase planning.

Empirical research is confirming the predictions of a frugal, cautious and thrifty postrecession consumer (Quelch \& Jocz, 2009; Flatters \& Wilmott, 2009; Piercy et al., 2010). Existing studies are also consistent with the prediction of increasing complexity in consumer behavior. As put by Piercy et al. (2010, p.4) the assumption that conditions will go back to "normal" and things will be as they were before the downturn may be fatally flawed. Simultaneously, marketing scholars' forecasts were also explicit regarding an increasing public skepticism and lack of trust in business and economy which, for example, might help to explain the slow recovery in US consumption despite improvements in economic performance (Pistaferri, 2016). This also indicates the indirect cognitive/emotional mechanism of crises (Koos, 2015; Koos et al., 2017), confirming that it is crucial to understand recession psychology and emotional reactions to the economic environment (Quelch and Jocz, 2009). 
Simultaneously, as emphasized by Koos et al. (2017), crises happen in a complex and multidimensional context that includes the role of past experience, civic ties and solidarity networks, that might attenuate and moderate the effect of a crisis. Aligned with this argument, recent empirical studies have demonstrated the positive and attenuating effect of new and innovative logics of production and supply, networks and community-based responses to crises (e.g. Blättel-Mink et al., 2017; Garner, 2017; Lindlbom \& Lindlbom, 2017).

\section{Method}

The research used a longitudinal approach, combining two qualitative studies. Our main objective was to broaden the breadth and depth of comprehension since longitudinal studies give greater power to data interpretation, allowing capturing real actions, instead of mere intentions. The combination of both studies provided a deeper understanding of the phenomenon, allowing an interpretation in a broader temporal spectrum.

Data from the qualitative studies were collected in two moments in time. The first in 2014, during the Portuguese recession, and the second in 2018, during the recovering process. Although Portuguese economic crisis had its peak in 2011, with the Portuguese government request for financial assistance to the European Commission, in 2014, Portuguese consumers were still facing hard times, dealing with several monetary limitations and high levels of unemployment. In 2013, the unemployment rate was $16,3 \%$ (four times higher than the $4 \%$ achieved in 2001) (Banco de Portugal, 2014) and the highest since the Portuguese democratic history (Pordata, 2018). In 2018, the country was already in a process of consolidation of the economic recovery with the economy growing $2.1 \%$ and with an unemployment rate of $7 \%$ (Banco de Portugal, 2019). 


\subsection{Data collection and analysis}

Data were collected in two moments in time (2014 and 2018), comprising a total of 22 interviews with 11 Portuguese consumers (two interviews per consumer). The consumers were selected through a snowball procedure (i.e. each interviewee nominated another person to participate in the study). The interviews were conducted on-site by the same interviewer to reduce bias. The first stage of data collection occurring in 2014 ended when theoretical saturation was reached (Yin, 1994). In 2018, a follow-up interview was conducted with each of the consumers. Table 1 provides the interviewees' profile in 2014 and changes occurred until 2018.

Two interview guides were developed and previously assessed by three academics. The 2014 interview guide covered the following topics: implications of the economic crisis in consumers' attitudes and routines and expectations regarding buying behavior after the recession. The 2018 interview guide comprised the following topics: consumers' perception regarding the Portuguese economic recovery; buying behavior during the economic recovery process; and consumer perceptions of negative and positive effects of the economic contraction period. All interviews used an informal style with the discussion starting at a broader level. The interviews were taped with the permission of the interviewees and typically lasted 40 minutes. The interviews were transcribed verbatim. A sample of three transcripts in each data collection stage was returned to the respective informants to assess the transcription accuracy and no changes were asked. A thematic approach was used to code the data and generate meaning. The analysis involved inductive reasoning placing a significant emphasis on verbatim quotations from informants. One researcher classified the data throughout various iterations and a second researcher cross-checked the information to achieve intercoder reliability (i.e. commonality in coding) (Perreault \& Leight, 1989). To 
further assess reliability and credibility (Lincoln \& Guba, 1985), the main findings were checked with a pool of five consumers.

Insert table 1 here

\section{Findings and global discussion}

This section presents the results of the qualitative studies, systematizing the main themes identified in each research topic: i) consumer attitudes during recessions; ii) consumer intentions regarding the post-recession stage; iii) consumer attitudes during the recovery stage (Figure 1); and iv) consumer perceptions of negative and positive crisis outcomes (Figure 2). The results are presented in the context of extant literature. We now discuss each topic and the corresponding identified themes in more detail.

Insert figure 1 here

\subsection{Consumer attitudes during recessions}

Increased price relevance and higher propensity to buy private labels and national

brand promotions. Interviewees mentioned that, during the hard times of recession, the price of the products became determinant in their choices and the main concern was to save some money. This conclusion aligns with Ang (2001), who argues that the great adjustments in a crisis are price related. Research demonstrates that crises increase price consciousness 
(Burton et al., 1998) and price conscious consumers look forward to save money either buying more private labels or promotions (e.g. Garretson et al., 2002; Lamey et al., 2007). Our results confirm this trend. During recessions, besides buying more private labels, interviewees mentioned the continuous search for promotions in a view to cut back on their spending, as the following quotes illustrate:

- «The crisis had an impact on my family... now, I must look much more for the price than before ... I look for private labels and promotions...» [Inês - Married, one daughter, and two sons, five people in the household, 2014].

- «With the economic crisis, I buy more private labels. I have less money! In the past, I also used to buy private labels, but now I buy a lot more! .... I also care about the promotions of the week » [José-Divorced, one daughter, living with his father, 2014].

Higher organization and planned behavior. Interviewees referred to more balanced behaviors during recessions. The process of searching for good quality products with the best prices implies more organization and planned behavior. Previous research also highlighted that economic contractions shake consumers out of their habitual decision-making and inertia, leading to more shopping and information search and to a more careful evaluation of different purchase alternatives (Lamey, 2014; McKenzie \& Schargrodsky, 2005). The following quotes convey consumers' adoption of this proactive behavior:

- «With the economic crisis, I began to make financial records, which was something I had never done! I make calculations. I see which supermarkets are cheaper... before the crisis, I bought indiscriminately any product regardless of the price. »[Teresa-Married, one daughter and one son, two people in the household, 2014]. 
- «I am very attentive to the promotions of the week and I try to organize myself to enjoy the best I can! » [Tiago - Divorced, one daughter and one son, three people in the household, 2014].

Higher purchase frequency and reduced stocking behavior. Interviewees mentioned the adoption of additional crisis mitigation mechanisms like going shopping more often and avoiding excessive stocking. The prevalence of increased shopping during recessions is also highlighted in the literature (e.g. McKenzie \& Schargrodsky, 2005; Shama, 1981). For example, McKenzie \& Schargrodsky (2005) refer that Argentine households 'bought less, but shopped more' during the 2002 Argentine economic crisis. Avoiding stocking was another way to reduce consumption expenditures and cope with economic constraints. The following interviewees' quotes illustrate these crisis mitigation mechanisms:

- «Another thing I try to do is less pantry, less storage! For example, I used to buy four packets of rice. But now I only buy two, and then, when I see that I only have one, I buy more. It does not pay to draw money! » [Ana Paula-Divorced, one daughter, two people in the household, 2014].

- «I go shopping more often...this allows me to buy the promotions of the week. I think more about things! » [Teresa-Married, one daughter and one son, two people in the household, 2014].

- «... I try to go more often (to the supermarket) and buy less... now I have a completely different philosophy of life... I am more contained... » [Beatriz Married, two sons, four people in the household, 2014].

Increased social responsibility. Consumers referred to the increased social responsibility associated with the economic recession and mentioned an additional concern of 
not wasting. Similarly, existing research emphasized the role of crises as drivers of more responsible behaviors and consumers' personal growth (Berdysheva \& Romanova, 2017) revealing that consumers are least wasteful during these stages (e.g. Ang, 2001; Shama, 1981). The following quotes corroborate these behaviors:

- «I buy less, more often...to make sure I'm not going to waste! Wasting is an irresponsible behavior, particularly in these hard times. » [Tiago - Divorced, one daughter and one son, three people in the household, 2014].

- «I refuse to throw clean water down the sewer pipe!!!! When I'm taking a shower, I fill in some bottles until the water comes out hot! And I use that clean water in the toilet. It is a habit that I have to save money, but also for ecological purposes. Social responsibility is a concern to me! » [Ana Paula-Divorced, one daughter, two people in the household, 2014].

- «I became a more responsible consumer ... wasting is something that worries me! » [Teresa-Married, one son, two people in the household, 2014].

- «We have many superfluous things and the crisis has increased our social responsibility. » [Inês-Married, one daughter, and two sons, five people in the household, 2014].

\subsection{Consumer future intentions (post-recession stage)}

Internalized learning/enduring saving habits. Respondents mentioned that the crisis served as a learning context. Consumers learned to be more rational and more spared, a situation that also forced them to be more planned and organized. Interviewees were able to identify a new attitude, clearly stating that if the country's financial situation improved, they would not change the consuming habits acquired in the meantime. The following interviewees' quotes illustrate this phenomenon: 
- «If the situation of the country enhanced, I would maintain my attitude... That's how we learn. We are much more disciplined. The crisis also educates...» [Tiago - Divorced, one daughter, and one son, three people in the household, 2014].

- «... If the country's financial situation improved, I would not change anything. As a person, I got better with the crisis! I think the crisis makes great mental reforms to people... it grounds them to reality... it makes them look at things in a different way. They will learn a lot! » [Beatriz-Married, two sons, four people in the household, 2014].

- «... If the financial situation of the country improved, I could change my behavior slightly, but not in the essence because I have already internalized that it is better to be spared. I do not want to lose this habit. I want to keep this habit forever! I internalized to be spared» [Teresa-Married, one daughter and one son, two people in the household, 2014].

\subsection{Consumer attitudes during the recovery stage}

Macroeconomic data vs consumer perceptions. In 2018, Portugal was consolidating the process of economic recovery, with macroeconomic data mirroring this recovery process. In 2017, the GDP - Gross Domestic Product grew 2.8\%. In 2018, the economic activity in Portugal continued to expand (GDP growth of 2.1\%), albeit at a slower pace than in 2017 (Banco de Portugal, 2019). The unemployment rate also continued to decline, from $8,9 \%$ in 2017 to $7 \%$ in 2018 (Pordata,2019).

Although the economic recovery is translated into the macroeconomic figures, Portuguese consumers expressed their incredulity in these statistics because, on the one hand, they do not experience such a substantial improvement in their lives and, on the other hand, they do not believe that this improvement is sustainable. In their opinion, for example, 
unemployment figures are misleading and tourism-based economic growth poses huge risks due to the volatility of this sector. The inevitable growth of the current low interest rates also threatens consumers. The following quotes illustrate these ideas:

- «Unemployment data is camouflaged. It is camouflaged because the numbers only reflect those people who are receiving a subsidy. And those of long duration who stopped receiving subsidy? Those are in limbo, you do not even know where they are! Neither are employed nor unemployed!! ... those numbers do not reproduce the truth of the facts! (...) My life is almost at the same level (referring to the crisis period). I would like to go back to the gym, for example, but I cannot afford that additional effort yet» [Ana Paula-Divorced, one daughter, two people in the household, 2018].

- «I have heard that depending on tourism alone is a fragile situation, but it is better than nothing... At this moment we live a hollow abundance... hollow ... hollow, it has no foundations!...» [Teresa-Married, one daughter and one son, two people in the household, 2018].

- «The crisis has been overcome, but I do not know how long this will last! This air bubble!! I think that from the moment the interest rates will start to raise everything will change! It's going to change for the worse at the European level, not just in Portugal! Tourism also helps... My life as a consumer has improved a little, but it is something that will not last for long» [Tiago-Married, two daughters, and two sons, five people in the household, 2018].

- «I do not believe in the Government figures, because, for example, people who are unemployed are no longer enrolled in the Employment Center because they do not believe in the Institution. Many people were already registered there and saw that being enrolled was useless. Since they are not registered now, they do not count 
for the statistics! ... You see that there is unemployment! »[Beatriz-Married, two sons, four people in the household, 2018].

Assumed structural learning and saving habits acquired during the recession. In

2018, concurring with the economic recovery stage, interviewees reported that they maintained the savings habits acquired during the recession and that they intend to continue these practices for the rest of their lives. Pistaferri (2016) also found that US consumers remained thrifty after the recent great recession confirming other researchers that forecasted enduring frugality after the economy had technically left recession (e.g. Flatters \& Willmott, 2009; Quelch \& Jocz, 2009).

Interviewees further reported that they have maintained several practices acquired during the crisis period. They continue to buy private labels and national brand promotions; buy more often and in less quantity, except in the case of promotions. Consumers also feel that they are socially more responsible and more concerned about not wasting. The following interviewees' quotes illustrate these phenomena:

- «I continue to be very spared! I might buy a little more here and a little more there, but nothing significant! I continue very much in control!!! I continue to buy private labels and national brand promotions, in this case, I buy in quantity to take advantage of the discounts. Saving is a good practice!!! The crisis also educated me for saving. I was already spared before the crisis, but now I became even more spared! I think this behavior will stay with me for the rest of my life [Tiago Married, two daughters, and two sons, five people in the household, 2018].

- $\quad \ll I$ continue to buy private labels and promotions. Since the crisis, I have acquired this habit. I save 'something' and avoid squandering.... »[Teresa-Married, one son, two people in the household, 2018]. 
- «The saving habits that I acquired with the crisis will remain forever!!!!! We do not know what the future holds... the generations that went through the war, I remember my grandfather, my grandmother... There is no one of that generation that was 'a spender'! Even having a lot of money! They were all extremely spared... I think the crisis had educational advantages in these current generations, in mine, for example, and especially in the youngest» [Teresa-Married, one daughter and one son, two people in the household, 2018].

- «I continue very attentive to promotions! The crisis turned me a better consumer. More responsible and I think this learning is consistent... I think everyone has become used to saving and this learning is consistent. I keep going shopping more often and buy less each time. I hate wasting! » [José-Divorced, one daughter, living with his father and daughter, 2018].

Following the attempt to save money, consumers also revealed that they had become more organized in their purchases. They manage expenditures by categories, hierarchizing and accounting, either by means of a written record or only mentally. This grouping by category allows giving priority to fixed costs such as, for example, housing, water or electricity. On a second level, consumers place the variable costs which can be managed with greater containment or even suppressed. The following quotes illustrate these ideas:

- «I have a little book where I put all the expenditures by categories: grocery, gas, electricity, etc... I try to control!!! Of course, there are times when we need to spend more, for example at the beginning of the school year! Kids need more stuff (...) I think the method of writing in the booklet works very well. As I write, I have better control, but it was a practice that I acquired, especially with the crisis 
and that I still maintain» [Inês - Married, one daughter, and two sons, five people in the household, 2018].

- «My priority in the week I receive the salary is to pay everything that is a bill! I pay everything! And then, with the remaining money, I do the rest!!» [Ana Paula - Divorced, one daughter, two people in the household, 2018].

- « (...) in the first place is my son's education! Then is food, gas, electricity, etc., I mentally categorize. Clothes are always at the end! » [Teresa-Married, one son, two people in the household, 2018].

- «I have always organized the budget by categories. The food, water, electricity, that is, the compulsory expenses and then the rest! » [Sofia-Widow, one daughter and one son / living in a retiring house, 2018].

\subsection{Consumer perceptions of negative and positive crisis' outcomes}

Interviewees also presented their views regarding the most negative and positive outcomes of the economic crisis, both in individual and societal terms (Figure 2). Recent research also highlights the importance of discussing the effects of crises in society, uncovering how social imaginary of consumption alters the discourses and impacts on civic and political movements (Alonso et al., 2015, 2017; Koos et al., 2017).

Insert figure 2 here

Crisis negative outcomes. In terms of negative personal effects, interviewees mentioned the insecurity regarding the future that crises generally engender. The fear of another economic recession is something that worries consumers. This uncertainty and fear 
about the future is a crisis effect frequently conveyed in the literature (e.g. Alonso et al., 2015, 2017; Hampson \& McGoldrick, 2013; Kaytaz \& Gul, 2014). For example, Alonso et al. (2017) not only referred to the anxiety regarding the future, but also to the notorious pessimism of Spanish citizens after the 2007/2008 recession.

The psychological effects that crises leave on people were also highlighted by interviewees, such as feelings of sadness, depression, discontentment and demotivation. Shama (1981) also reported feelings of frustration and distress among US consumers faced with changes in the economic environment, such as shortage, inflation and recession. Although already living in the recovery stage, interviewees mentioned that these psychological effects on consumers are wounds that will take time to heal. The following quotes corroborate these ideas:

- «I see people generally demotivated, especially in public services...in Social Security, at the Post Office! The people complaining... this did not change yet! these are still the remnants of the crisis!!! And above all the general discontent. For example, the teachers are not motivated enough and this is reflected in the students because they do not have so much patience. » [Inês-Married, one daughter, and two sons, five people in the household, 2018].

- « (...) in psychiatric terms I think people are sad, it is not only me .... The crisis has caused deep wounds that will take a long time to heal and people are disbelieving because they do not see enough changes. They do not see solutions!» [Beatriz-Married, two sons, four people in the household, 2018].

- « (...) fear of the future..., even those that are employed are afraid of the future! » [Fátima - Widow, one daughter and three sons, living by herself, 2018]. 
In terms of the crisis main negative impact in society, consumers mentioned unemployment as the most evident. In many cases, resulting as a consequence of the higher levels of unemployment, consumers also highlighted other adverse outcomes such as emigration, particularly the more prepared youngest generation, poverty/misery and increased criminality. Consumers also mentioned the crisis of values that generally is associated with the economic crisis, which in the Portuguese case was particularly relevant since it affected governmental institutions and is compounded by a recognized inefficient justice system. Regarding the role of Governments, Alonso et al. (2017) also refer to a new discourse in Spain that blames the political class for the catastrophic management of the country.

Empirical research in Argentina further revealed that consumers do not trust the Government to surmount the crisis and evidenced a total lack of confidence in the political parties (Zurawicki \& Braidot, 2005). During recessions, people tend to punish the perceived sources of their dire circumstances (Flatters \& Willmott, 2009). The following interviewees' quotes convey these problems and their impact on society:

- «The number of people I know who became unemployed...It is incredible! At 40, 50 years old. It will be very difficult for them to find a new job, particularly at that age!! » [Sofia - Widow, one daughter and one son / living in a retiring house, 2018].

- $\quad$ «We see much-hidden poverty... people who were left with nothing! Literally! and are ashamed of their situation...Criminality also increased. My mother's and my son's houses were stolen. I never saw anything like that! » [Teresa-Married, one daughter and one son, two people in the household, 2018].

- «We live in a crisis of values, in my view! There is no investment and when there is, companies invest in the youngest to exploit them...to take advantage of them and pay a ridiculousness. That is why they are leaving the country... the kids are 
going to invest somewhere else (...) and all these situations that came to the public of Sócrates, Salgado (refereeing to the Portuguese ex-prime minister and a banker that are accused of corruption) ... People are sad because half a dozen people had ended with this country! Now it is a psychological crisis and a crisis of values» [Beatriz-Married, two sons, four people in the household, 2018].

Crisis positive outcomes. Although the negative impact of economic crises is more evident, consumers were also able to identify positive consequences of economic recessions, both in individual and societal terms. In terms of personal impact, consumers emphasized the aforementioned learning regarding higher levels of discipline and saving habits. They also referred to the diminished recourse to credit, which is important since they found that many of the problems that families had to overcome were due to the high indebtedness that occurred before the crisis. Consumers also mentioned the increase of spirituality and the appreciation of dimensions that go beyond the monetary issue. Shama (1981) also refers to a social movement that advocates voluntary simplicity. That is, declined disposable income results in changes in the consumer value system that tends to resort to material simplicity, functionalism and a more humanly lifestyle. Times of recession call for a new vision of society and human purpose with a higher focus on intangible resources like culture and spirituality (Dahl, 2009). The following interviewees' quotes illustrate these ideas:

- «I think that people have been forced to think more about life and to spend less and that is good! » [Alexandra-Retired/single living by herself, 2018].

- «(...) I see a higher appeal to spirituality! People are not so focused on the material part...I think that people should also find some refuge in culture! » [Teresa-Married, one son, two people in the household, 2018]. 
- $\quad$ «I have realized that people do not resort so much to credit, and Banks do not give credit so easily, which is a good achievement »[Teresa-Married, one daughter and one son, two people in the household, 2018].

Regarding the crisis' positive impact in society, interviewees referred to the higher solidarity and volunteering network movements. Additionally, the Government has become more responsible in terms of spending and investment, in part as a result of the increased transparency and institutional and social control. Alonso et al. (2017) also argue that the way people perceive the crisis affects political mobilization and higher scrutiny of Governments. Collective movements can voice consumer interests and push for political solutions to the crisis-induced problems (Koos et al., 2017). Economic downturns also develop dynamics of social resilience (e.g. Berdysheva \& Romanova, 2017, Garner, 2007). The following interviewees' quotes illustrate these ideas:

- «In practical terms, crises bring people together. Solidarity increases and this is good. People are more concerned about each other and they lean more on each other and that is good...» [Conceição - Widow, two daughters, and one son, living by herself, 2018].

- «The Government does not spend money so badly! ...Tends to spend money better. Now the State has begun to be more careful with money, it is not like before! »[Tiago-Married, two daughters, and two sons, five people in the household, 2018].

- «One of the advantages of the crisis was the discovery of corruption cases like the case of BES (referring to the Portuguese bank accused of corruption). Maybe without the economic crisis, 'they' (the ones involved in corruption) would never 
be discovered because there was a lot of money and no one cared! » [BeatrizMarried, two sons, four people in the household, 2018].

\section{Conclusions and directions for further research}

The main objective of this research is to contribute to the discussion regarding consumer attitudes in periods of economic downturn and in the immediate recovery stage, answering to the call for papers addressing changes in consumer behavior during recessions and looking for the consistency of those changes over time (Kaytaz \& Gul, 2014, Koos et al., 2017; Zurawicki \& Braidot, 2005). In particular, we shed light into the understanding of consumer behavior during recessions and evaluate whether the identified practices persisted after the recession was over, expanding existing literature in the field.

Economic recessions constitute 'periods of change', engendering moments of human reflection that influence consumer behavior and new adjustments to lessen economic resources (see Koos et al., 2017). Our study confirms that, under these circumstances, consumers become more price sensitive (see also Ang, 2001; Burton et al., 1998) and more focused on making good (better) decisions through more rational trade-offs. In general, as a result of the increased price consciousness, consumers are more willing to spare some money, opting for cheaper solutions, such as private labels and promotions (see Garretson et al., 2002; Lamey et al., 2007). Following the attempt to save money, consumers also revealed they manage expenditures by categories, hierarchizing and accounting, either by means of a written record or only mentally. This grouping into different categories reinforces Thaler's $(1985,1999)$ argument that mental accounts help individuals to simplify their financial decision-making. The relevance of price during recessions became clearly reflected in the study findings, which also revealed that consumers continued to be price conscious in the recovery stage. 
During recessions, consumers develop different coping strategies pursuing economic level-headedness and assuming new behaviors that allow them to accommodate the reduced income (see Shama, 1981). Besides switching to cheaper options, consumers revealed new strategies and new habits, such as increased social responsibility; more organization and planned behavior; going shopping more frequently; reducing stocking behavior; and, avoiding wasting. These coping strategies were adopted to mitigate the crisis' effects and were rationally interpreted as conscious routines making part of a new logic of consumption.

Our study expands the comprehension of consumer behavior during recessions, bringing the idea of crises as 'learning opportunities', instigating structural changes in people's lives. Coping behaviors adopted during the recession stage were assimilated and became part of consumers' everyday life configurations and routines. The consumers claimed that nothing will be the same, once they learned the lesson and intend to continue to be thoughtful and responsible consumers for the rest of their life. The adoption of a longitudinal approach, comprising both the recession and the recovery stages confirmed that consumers effectively maintained the practices learned during the recession stage and continued to be spared and frugal when the crisis ended, as they had predicted. This conclusion confirms the expectations of other researchers that forecasted enduring frugality in consumer behavior after the economy had left the recession (e.g. Quelch \& Jocz, 2009) and aligns with Lamey (2014) who posits that, for example, the increase in discounters' share during recessions remains after the crisis is over.

The discussion regarding the demand for simplicity (see Flatters \& Willmott; Shama, 1981) became further reflected in the study findings. Focusing on the recession and postrecession dynamics, the research uncovered a new logic of consumption edified in mature consumers who look for simple offerings with greatest value. Consumers highlighted the raised appreciation of dimensions that go beyond the monetary issue, where spirituality, 
culture and other forms of individual and social expression and civilization emerge as fundamental pillars of the dominant value system. This new vision alters the discourses and the social imaginary of consumption, leading citizens to re-think their positioning towards a consumption ecosystem traditionally ruled by a materialistic philosophy and unsustainable practices.

Substantively, there are several directions for extending our work. First, our findings can be strengthened with an extension to different contexts. Possible settings for future studies are different nations and individual societies facing economic recessions. Such diversity will allow capturing consumers specific lifestyles and contextual differences and approaches. Second, future research should also systematize buying behavior in periods of economic contraction, taking into account the consumers' demographic characteristics, as they might also explain consumer idiosyncrasies and behaviors. Third, further research should study the crisis effects from the business's perspective, understanding how companies absorb and react to more demanding citizens during and after recessions. Finally, future studies could explore alternative segmentation frameworks that include emotional and political reactions to recessions, as well as new configurations concerning the psychological categorization of purchases, namely from essentials to superfluous and from utilitarian to hedonic.

\section{References}

Alonso, L.; Rodríguez, C.; Rojo, R. (2017). "I think the middle class is disappearing”: Crisis perceptions and consumption patterns in Spain. International Journal of Consumer Services, 41, 389-396.

Alonso, L.; Rodríguez, C. \& Rojo, R. (2015). From consumerism to guilt: Economic crisis and discourses about consumption in Spain. Journal of Consumer Culture, 15(1), 66-85. 
Ang, S. H. (2001). Crisis marketing: A comparison across economic scenarios. International Business Review, 10(3), 263-284.

Ang, S.H.; Leon, S.M.; Kotler, P. (2000). The Asian Apocalypse: Crisis Marketing for Consumers and Businesses. Long Range Planning, 33, 97-119.

Banco de Portugal (2014) Relatório do Conselho de Administração. A Economia Portuguesa, LISBOA, Banco de Portugal, available at https://www.bportugal.pt/sites/default/files/anexos/pdf-boletim/ra14ep_pt.pdf (accessed 15 April 2018).

Banco de Portugal, 2019. Boletim Económico de Março de 2019. available at. https:// www.bportugal.pt/sites/default/files/anexos/pdf-boletim/be_mar2019_p.pdf Accessed 3 May 2019.

Berdysheva. E. \& Romanova, R. (2017). Rethinking prices during an economic crisis: Calculation as a new mode of consumer behaviour in Russia. International Journal of Consumer Studies, 41, 397-403.

Blättel-Mink, B.; Boddenberg, M.; Gunkel, L.; Schmitz, S. \& Vaessen, F. (2017). Beyond the market-New practices of supply in times of crisis: The example community-supported agriculture. International Journal of Consumer Studies, 41, 415-421.

Burton, S.; Lichtenstein, D.; Netemeyer, R. \& Garretson, J. (1998). A Scale for measuring attitude toward private label products and an Examination of its psychological and behavioral correlates. Journal of the Academy of Marketing Science, 26 (4), 293-306.

Cutler, F. (1979). Overview of the 'longitudinal research design and analysis of panel data' workshop. Advances in Consumer Research, 6(1), 31-33.

Dahl, A. (2009). The financial crisis and consumer citizenship. Proceedings of the $6^{\text {th }}$ International Conference of the Consumer Citizenship Network. Berlin, 23-24 March.

Deleersnyder, B., Dekimpe, M., Sarvary, M., \& Parker, P. (2004). Weathering tight economic times: The sales evolution of consumer durables over the business cycle. Quantitative Marketing and Economics, 2, 347-383.

Du, R., \& Kamakura, W. (2008). Where did all that money go? Understanding how consumers allocate their consumption budget. Journal of Marketing, 72, 109-131.

Ehrlinger, J., Readinger, W. O., \& Kim, B. (2015). Decision Making and Cognitive Biases. In H.S. Friedman (Ed.), Encyclopedia of Mental Health, 2E, Vol. II. Philadelphia, PA: Elsevier, 5-12.

Flatters, P. \& Willmott, M. (2009). Understanding the post-recession consumer. Harvard Business Review, July-August, 106-112. 
Garner, B. (2017). Communicating social support during crises at the farmers' market: A social exchange approach to understanding customer-farmer communal relationships. International Journal of Consumer Studies, 41, 422-430.

Garretson, J.; Fisher, D. \& Burton, S. (2002). Antecedents of private label attitude and national brand promotion attitude: similarities and differences. Journal of Retailing, 78, 91-99.

Hampson, D.; Grimes, A.; Banister, E. \& McGoldrick (2018). A typology of consumers based on money attitudes after major recession. Journal of Business Research, 91, 159-168.

Hampson, D. \& McGoldrick, P. (2017). Antecedents of consumer price consciousness in a turbulent economy. International Journal of Consumer Studies, 41, 404-414.

Hampson, D. \& McGoldrick, P. (2013). A typology of adaptive shopping patterns in recession. Journal of Business Research, 66, 831-838.

Jacoby, J. (2000). Is it rational to assume consumer rationality? Some consumer psychological perspectives on rational choice theory, Roger Williams University Law Review, 6 (1), 83161.

Kamakura, W., \& Du, R. (2012). How economic contractions and expansions affect expenditure patterns. Journal of Consumer Research, 39, 229-247.

Kaswengi, J. \& Diallo, M. (2015). Consumer choice of store brands across store formats: A panel data analysis under crisis periods. Journal of Retailing and Consumer Services, 23, 70-76.

Kaytaz, M. \& Gul, M. (2014). Consumer response to economic crisis and lessons for marketers: The Turkish experience. Journal of Business Research, 67 (1), 2701-2706.

Koos, S. (2015). Crises and consumption. In M. Keller, B. Halkier, T. Wilska, \& M. Truninger (Eds.), Routledge handbook on consumption, 131-142. Oxford: Routledge.

Koos, S.; Vihalemm, T.; Keller, M. (2017). Coping with crises: Consumption and social resilience on markets. International Journal of Consumer Studies, 41, 363-370.

Lamey, L. (2014). Hard economic times: a dream for discounters. European Journal of Marketing, 48 (3/4), 641-656.

Lamey, L.; Deleersnyder, B.; Dekimpe, M. \& Steenkamp, J. (2007). How business cycles contribute to private-label success: Evidence from the United States and Europe. Journal of Marketing, 71 (January), 1-15.

Lekakis, E. J. (2017). Economic nationalism and the cultural politics of consumption under austerity: The rise of ethnocentric consumption in Greece. Journal of Consumer Culture, 17(2), 286-302.

Lincoln, Y. \& Guba, E. (1985), Naturalistic Inquiry, Sage, Newbury Park, CA. 
Lindblom, A., \& Lindblom, T. (2017). De-ownership orientation and collaborative consumption during turbulent economic times. International Journal of Consumer Studies, 41, 431-438.

Mathis K. \& Steffen A. (2015). From rational choice to behavioural economics. In: Mathis K. (eds) European Perspectives on Behavioural Law and Economics. Economic Analysis of Law in European Legal Scholarship, vol 2. Springer.

McKenzie, D. \& Schargrodsky, E. (2005). Buying less, but shopping more: Changes in consumption patterns during a crisis. Business School Working Papers, Universidad Torcuato Di Tella.

Nunes, J.; Drèze, X. \& Han, Y. (2011). Conspicuous consumption in a recession: Toning it down or turning it up? Journal of Consumer Psychology, 21 (2), 199-205.

Perreault, W. \& Leigh, L. (1989). Reliability of nominal data based on qualitative judgments. Journal of Marketing Research, 26(2), 135-148.

Piercy, N.; Cravens, D. \& Lane, N. (2010). Marketing out of the recession: recovery is coming, but things will never be the same again. Marketing Review, 10 (1), 3-23.

Pistaferri, L. (2016). Why has consumption remained moderate after the Great Recession? Stanford Working Papers. available from: https://web.stanford.edu/ pista/cons_recess_August_2011.pdf

Pordata (2018) available at https://www.pordata.pt/Portugal/Popula\%C3\%A7\%C3\%A3o+desempregada+total+e+por+ dura\%C3\%A7\%C3\%A3o+da+procura+de+emprego-360 (accessed in 15 April 2018).

Pordata, 2019, available at https://www.pordata.pt/DB/Portugal/Ambiente+de

+Consulta/Tabela. Accessed 3 May 2019.

Puelles, M., Diaz-Bustamante \& Carcelén, S. (2016). Are consumers more rational and informed purchasers during recession periods? The role of Private Labels and retailing strategies. The International Review of Retail, Distribution and Consumer Research, 26(4), 396-417.

Quelch, J. A., \& Jocz, K. E. (2009). How to market in a downturn. Harvard Business Review, $87(4), 52-62$.

Shama, A. (1981). Coping with Stagflation: Voluntary simplicity. Journal of Marketing, 45, 120-134.

Srinivasan, R.; Rangaswamy, A.; Lilien, G.L. (2005). Turning adversity into advantage: Does proactive marketing during a recession pay off? International Journal of Research in Marketing, 22, 109-125. 
Steenkamp, J. \& Mayden-Olivares, A. (2015). Stability and Change in Consumer Traits:

Evidence from a 12-Year Longitudinal Study, 2002-2013. Journal of Marketing Research, 52 (3), 287-308.

Strutton, D. \& Lewin, J. (2012) Investigating consumers' responses to the Great Recession. Journal of Consumer Marketing, 29 (5), 378-388.

Thaler, R. (1985). Mental accounting and consumer choice. Marketing Science, 4, (3), 199214.

Thaler, R. (1999). Mental Accounting Matters. Journal of Behavioral Decision Making. 12, 183-206.

The Royal Swedish Academy of Sciences, 2017. Scientific Background on the Sveriges Riksbank Prize in Economic Sciences in Memory of Alfred Nobel. available at: https://www.nobelprize.org/uploads/2018/06/advancedeconomicsciences2017. pdf.

Vihalemm T; Keller M. \& Pihu K. (2016). Consumers during the 2008-2011 Economic Crisis in Estonia: Mainstream and Grass Roots Media Discourses. Italian Sociological Review, 6 (1), 57-86.

Xiao, J., \& O’Neill, B. (2016). Consumer financial education and financial capability. International Journal of Consumer Studies, 40, 712-721.

Yin, R. (1994). Case Study Research - Design and Methods, Sage, London.

Zurawicki, L., \& Braidot, N. (2005). Consumers during crisis: Responses from the middle class in Argentina. Journal of Business Research, 58 (8), 1100-1109. 
Table 1: Profile of interviewees (2014 vs 2018)

\begin{tabular}{|c|c|c|}
\hline \multirow{2}{*}{ Name } & 2014 & 2018 \\
\hline & Age/Education/ Occupation/Family status & Changes in the interviewees' profile \\
\hline Teresa & $\begin{array}{l}\text { 55/Biologist/unemployed/ married, one } \\
\text { daughter and one son, two people in the } \\
\text { household }\end{array}$ & $\begin{array}{l}\text { 59/Biologist/unemployed/ married, one } \\
\text { daughter and one son, two people in the } \\
\text { household }\end{array}$ \\
\hline Conceição & $\begin{array}{l}\text { 62/Primary school/housekeeper/ widow, two } \\
\text { daughters, and one son, living by herself }\end{array}$ & $\begin{array}{l}\text { 66/Primary school/housekeeper/ widow, } \\
\text { two daughters, and one son, living by } \\
\text { herself }\end{array}$ \\
\hline Beatriz & $\begin{array}{l}\text { 47/Engineer/unemployed/ married, two sons, } \\
\text { four people in the household }\end{array}$ & $\begin{array}{l}\text { 51/Engineer/unemployed/ married, two } \\
\text { sons, four people in the household }\end{array}$ \\
\hline Ana Paula & $\begin{array}{l}48 / \text { High school/multimedia content } \\
\text { manager/ divorced, one daughter, two } \\
\text { people in the household }\end{array}$ & $\begin{array}{l}\text { 52/High school/multimedia content } \\
\text { manager/ divorced, one daughter, two } \\
\text { people in the household }\end{array}$ \\
\hline Alexandra & $\begin{array}{l}\text { 49/High school/retired/ single living by } \\
\text { herself }\end{array}$ & $\begin{array}{l}\text { 53/High school/retired/ single living by } \\
\text { herself }\end{array}$ \\
\hline Fátima & $\begin{array}{l}\text { 82/High school/retired/ widow, one daughter } \\
\text { and three sons, living by herself }\end{array}$ & $\begin{array}{l}\text { 86/High school/retired/ widow, one } \\
\text { daughter and three sons, living by herself }\end{array}$ \\
\hline Inês & $\begin{array}{l}\text { 49/Doctorate/unemployed/ married, one } \\
\text { daughter and two sons, five people in the } \\
\text { household }\end{array}$ & $\begin{array}{l}\text { 53/ Doctorate/unemployed/ married, one } \\
\text { daughter and two sons, five people in the } \\
\text { household }\end{array}$ \\
\hline Teresa & $\begin{array}{l}\text { 54/Degree level/ teacher/ married, one son, } \\
\text { three people in the household }\end{array}$ & $\begin{array}{l}\text { 58/ Degree level/ teacher/ married, one } \\
\text { son, two people in the household }\end{array}$ \\
\hline Sofia & $\begin{array}{l}\text { 84/High school/ retired/ married, one } \\
\text { daughter and one son, two people in the } \\
\text { household }\end{array}$ & $\begin{array}{l}\text { 88/ High school/ retired/ widow, one } \\
\text { daughter and one son/living in a retiring } \\
\text { house }\end{array}$ \\
\hline José & $\begin{array}{l}\text { 48/high school/ salesman/ divorced, one } \\
\text { daughter, living with his father }\end{array}$ & $\begin{array}{l}\text { 52/high school/ salesman/ divorced, one } \\
\text { daughter, living with his father and } \\
\text { daughter }\end{array}$ \\
\hline Tiago & $\begin{array}{l}\text { 43/High school/ self-employed/ divorced, } \\
\text { one daughter, and one son, three people in } \\
\text { the household }\end{array}$ & $\begin{array}{l}\text { 47/High school/ self-employed/ married, } \\
\text { two daughters, and two sons, five people } \\
\text { in the household }\end{array}$ \\
\hline
\end{tabular}


Figure 1: Consumer attitudes during the recession and the recovery stages

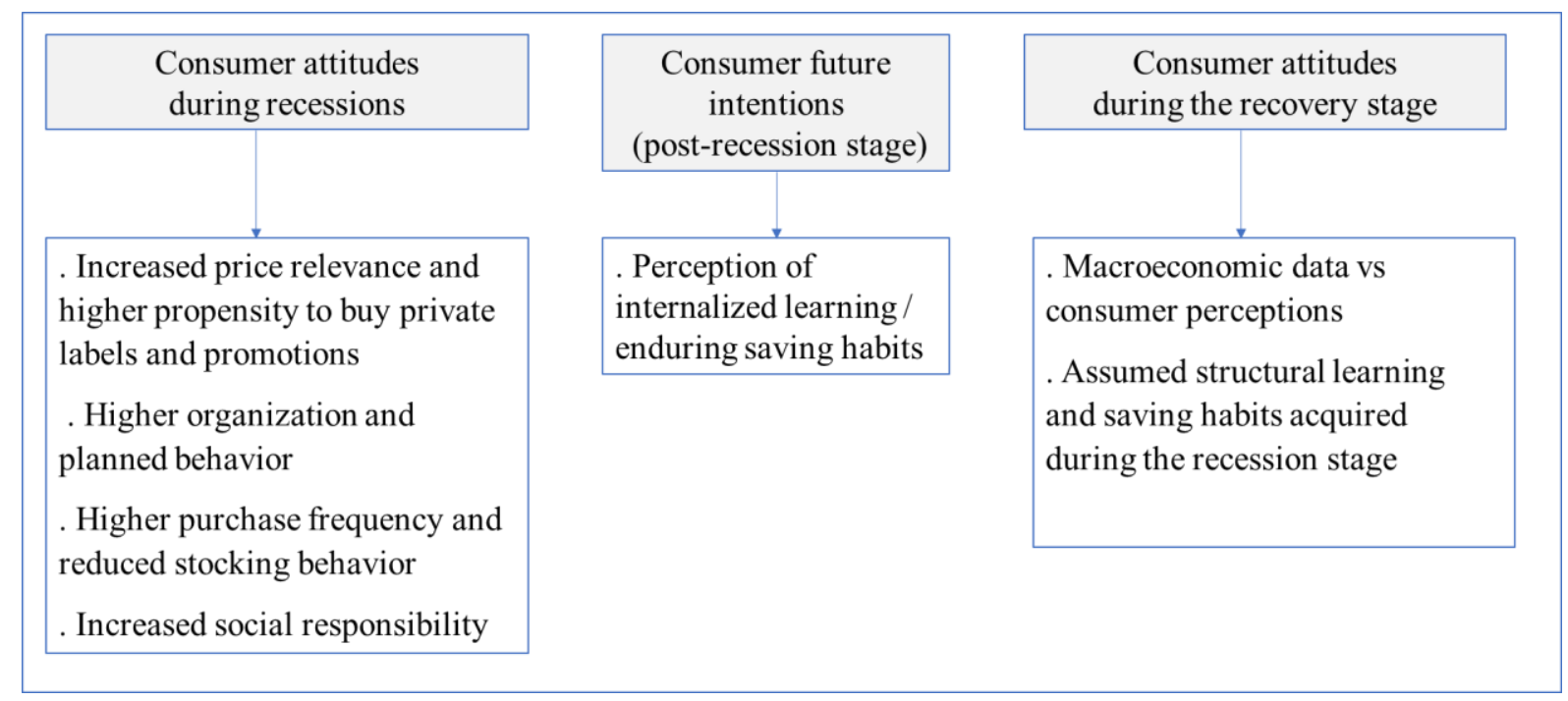


Figure 2: Consumer perceptions of negative and positive crisis' outcomes

\section{PERSONAL}

- Leaning in terms of discipline and saving habits

- Diminished recourse to credit

- Increased use of spirituality

SOCIETAL

- Solidarity / volunteering

- Government more judicious in spending

- Increased transparency and control

\section{PERSONAL}

- Insecurity regarding the future

- Demotivation

- Discontentment

- Depression

- Sadness

SOCIETAL

- Unemployment

- Emigration

- Values crisis

- Poverty/misery

- Increased criminality 